\title{
Networks and social cohesion in ancient Indian Ocean trade: geography, ethnicity, religion
}

\author{
Eivind Heldaas Seland \\ Department of Archaeology, History, Cultural Studies and Religion, University of Bergen, \\ P.O. Box 7805, N-5020 Bergen, Norway \\ E-mail: eivind.seland@ahkr.uib.no
}

\begin{abstract}
The Indian Ocean is famous for its well-documented Jewish and Islamic trading networks of the medieval and early modern periods. Social networks that eased the challenges of cross-cultural trade have a much longer history in the region, however. The great distances covered by merchants and the seasonality of the monsoons left few alternatives to staying away for prolonged periods of time, and shipwreck, piracy, and the slave trade caused people to end up on coasts far away from home. Networks of merchants developed in the Indian Ocean region that depended on a degree of social cohesion. This article draws up a map of selected merchant communities in the western Indian Ocean, and argues that geographical origin, ethnicity, and religion may have been different ways of establishing the necessary infrastructure of trust.
\end{abstract}

Keywords ethnicity, Indian Ocean, networks, religion, trade

\section{Introduction}

The western Indian Ocean was the central hub of ancient world trade. Chinese silk, Indian spices and textiles, African ivory, Arabian aromatics, Afghan gems, Egyptian glass, Syrian wine, and Spanish silver were among the many commodities that crossed the ocean in the hold of ships from all coasts of the Arabian Sea, Persian/Arabian Gulf, and Red Sea. ${ }^{1}$ As in later periods, the trade was made possible by the monsoon winds, which in the Arabian Sea blow steadily from the south-west from June to September/October, and from the north-east from November to April/May, ${ }^{2}$ thus facilitating predictable, although not necessarily smooth or safe, passage between all ports of call in the course of a year.

1 Roberta Tomber, Indo-Roman trade: from pots to pepper, London: Duckworth, 2008; Himanshu P. Ray, The archaeology of seafaring in ancient South Asia, Cambridge: Cambridge University Press, 2003; Raoul McLaughlin, Rome and the distant East: trade routes to the ancient lands of Arabia, India and China, London: Continuum, 2010, pp. 23-60; Steven E. Sidebotham, Berenike and the ancient maritime spice route, Berkeley, CA: University of California Press, 2011; Eivind Heldaas Seland, Ports and power in the Periplus: complex societies and maritime trade on the Indian Ocean in the first century AD, Oxford: Archaeopress, 2010.

2 National Imagery and Mapping Agency, PUB 109: Atlas of pilot charts for the Indian Ocean, 4th edn, Culver City, CA: National Imagery and Mapping Agency, 2001; Lionel Casson, The Periplus Maris 
Pre-modern trade in the Indian Ocean was far from plain sailing. The seasonality of the monsoon, combined with limited possibilities for overland travel, made communication between travelling merchants and their home base outside sailing seasons all but impossible, and as information rarely travelled faster than people, traders would seldom have information about local conditions before they were actually on the spot. Merchants operated under conditions set by their hosts, who, as Peder F. Bang points out in his recent monograph on comparative aspects of pre-modern trade, generally combined protection, taxation, and predation. ${ }^{3}$

The organizational solution to this situation was communities of resident merchants on foreign ground, generally called trading diasporas. The term was coined by Abner Cohen, ${ }^{4}$ and later developed by Phillip Curtin, who saw such groups as universal facilitators or go-betweens of pre-modern cross-cultural trade. ${ }^{5}$ Diaspora groups were experts on home and host cultures alike, and could provide the infrastructure of trust needed for people operating far away from home. Early examples are known from the second millennium BCE cuneiform archives from Anatolian Kültepe (Kanesh) ${ }^{6}$ and from the archaic period Greek settlement at Naucratis in the Nile Delta. ${ }^{7}$ In the Indian Ocean, the rhythm of the monsoons would in many cases cause visiting crews and merchants to spend a minimum of several months in their ports of call, waiting for the right season to return home. Some of them stayed behind, whether permanently or for shorter periods of time. Shipwreck, slavery, and personal circumstances also caused a significant number of Indian Ocean travellers to end up in places other than that of their origin.

Excellent studies exist of Indian Ocean merchant communities of the medieval and early modern periods ${ }^{8}$ but our knowledge of their ancient counterparts remains limited. The subject deserves a full-scale study but, pending that, this article is an attempt to look at some network aspects of ancient Indian Ocean trade as they appear in a selection of literary and epigraphic

Erythraei, Princeton, NJ: Princeton University Press, 1989, pp. 283-5; William Facey, 'The Red Sea: the wind regime and location of ports', in Paul Lunde and Alexandra Porter, eds., Trade and travel in the Red Sea region: proceedings of the Red Sea project I, held in the British Museum October 2002, Oxford: Archaeopress, 2004, pp. 7-17; Eivind Heldaas Seland, 'The Persian Gulf or the Red Sea? Two axes in ancient Indian Ocean trade, where to go and why', World Archaeology, 43, 3, 2001, pp. 398-409.

3 Peter Fibiger Bang, The Roman bazaar: a comparative study of trade and markets in a tributary empire, Cambridge: Cambridge University Press, 2008, pp. 131-201.

4 Abner Cohen, 'Cultural strategies in the organization of trading diasporas', in Claude Meillassoux, ed., The development of indigenous trade and markets in West Africa, London: Oxford University Press, 1971, pp. 266-84.

5 P. D. Curtin, Cross-cultural trade in world history, Cambridge: Cambridge University Press, 1984.

6 Mogens Trolle Larsen, 'The old Assyrian city-state', in Mogens Herman Hansen, ed., A comparative study of thirty city-state cultures: an investigation conducted by the Copenhagen Polis Centre, Copenhagen: Det Kongelige Danske Videnskabernes Selskab, 2000, pp. 77-87.

7 Herodotus, Histories, 2.154, 2.178, edited and translated in A. D. Godley, Herodotus: the Persian wars, vol. 1, Cambridge, MA: Harvard University Press, 1920.

8 Patricia Risso, Merchants and faith: Muslim commerce and culture in the Indian Ocean, Boulder, CO: Westview Press, 1995; S. D. Goitein, 'Portrait of a medieval India trader: three letters from the Cairo Geniza', Bulletin of the School of Oriental and African Studies, 50, 3, 1983, pp. 449-64; S. D. Goitein, Letters of medieval Jewish traders, Princeton, NJ: Princeton University Press, 1974; Roxani Eleni Margariti, Aden and the Indian Ocean trade: 150 years in the life of a medieval Arabian port, Chapel Hill, NC: University of North Carolina Press, 2007; S. D. Goitein and Mordechai Akiva Friedman, India traders of the Middle Ages: documents from the Cairo Geniza: India book, Leiden and Boston, MA: Brill, 2008; K. N. Chaudhuri, Asia before Europe: economy and civilisation of the Indian Ocean from the rise of Islam to 1750, Cambridge: Cambridge University Press, 1990. 
sources, and with the emphasis on institutions of social cohesion. What made people feel that they belonged to the same group? How could merchants establish the necessary infrastructure of trust? Examples are provided of trading communities organized along lines of geographical origin, ethnicity, and religion, and the argument is made that the development of Christian trading diasporas in late antiquity anticipates the existence of the better-documented Jewish and Islamic diasporas of later periods.

\section{Trading diasporas, circulation societies, and social networks}

The term 'diaspora' and the trading diaspora model in particular have recently drawn criticism. Rogers Brubaker points out that the use of 'diaspora' has become so widespread that it stands in danger of becoming unproductive as an analytical category. ${ }^{9}$ He proposes that, in order to qualify as true diasporas, communities must first be dispersed, second be oriented towards a real or imagined homeland, and third preserve a distinctive identity towards host societies. ${ }^{10} \mathrm{~S}$. D. Aslanian points out that the notion of trading diasporas presupposes a centre, or home culture as it was called above. This was not the case with the Armenian trading community studied by Aslanian, nor, for that matter, with the polycentric Jewish community documented in the Cairo Geniza, which included merchants permanently based in Egypt, South Arabia, and India, ${ }^{11}$ as well as in Mediterranean ports. Aslanian suggests instead the concept of 'circulation societies'. ${ }^{12}$ Valid as this distinction might be, on a more general level trading diasporas and circulation societies are simply two ways of characterizing networks of social and commercial interaction, and, arguably, both were represented in the western Indian Ocean in the ancient period. Here, the applications of social network analysis, such as that represented by the recent work of Irad Malkin and others on Greek networks in the Mediterranean might have something to offer, ${ }^{13}$ as it allows us to look at diasporas and circulation societies as two varieties of the same phenomenon.

Network analysis has a long tradition within the social sciences, ${ }^{14}$ and has made increasing impact within the humanities over the past decades. ${ }^{15}$ In a basic sense, of course,

9 Rogers Brubaker, 'The "diaspora” diaspora', Ethnic and Racial Studies, 28, 1, 2005, pp. 1-19.

10 Ibid., pp. 5-7.

11 Goitein, 'Portrait'; Goitein, Letters; Margariti, Aden; Goitein and Friedman, India traders.

12 Sebouh David Aslanian, From the Indian Ocean to the Mediterranean: the global trade networks of Armenian merchants from New Julfa, Berkeley, CA: University of California Press, 2011, pp. 1-22.

13 Irad Malkin, 'Networks and the emergence of Greek identity', Mediterranean Historical Review, 18, 2, 2003, pp. 56-74; Kostas Vlassopoulos, 'Beyond and below the polis: networks, associations, and the writing of Greek history', Mediterranean Historical Review, 22, 1, 2007, pp. 11-22; Irad Malkin, A small Greek world: networks in the ancient Mediterranean, New York: Oxford University Press, 2011; Irad Malkin, Christy Constantakopoulou, and Katerina Panagopoulou, eds., Greek and Roman networks in the Mediterranean, London: Routledge, 2011.

14 Stephen P. Borgatti, Ajay Mehra, Daniel J. Brass, and Giuseppe Labianca, 'Network analysis in the social sciences', Science, 323, 5916, 2009, pp. 892-5; Stanley Wasserman and Katherine Faust, Social network analysis: methods and applications, Cambridge: Cambridge University Press, 1994.

15 In addition to Malkin's work (see n. 13 above), see the modern classic John F. Padgett and Christopher K. Ansell, 'Robust action and the rise of the Medici, 1400-1434', American Journal of Sociology, 98, 6, 1993, pp. 1259-319; Giovanni Ruffini, Social networks in Byzantine Egypt, Cambridge: Cambridge University 
Figure 1. Network with six nodes and two clusters centred on nodes A and B. Source: all figures are the work of the author.

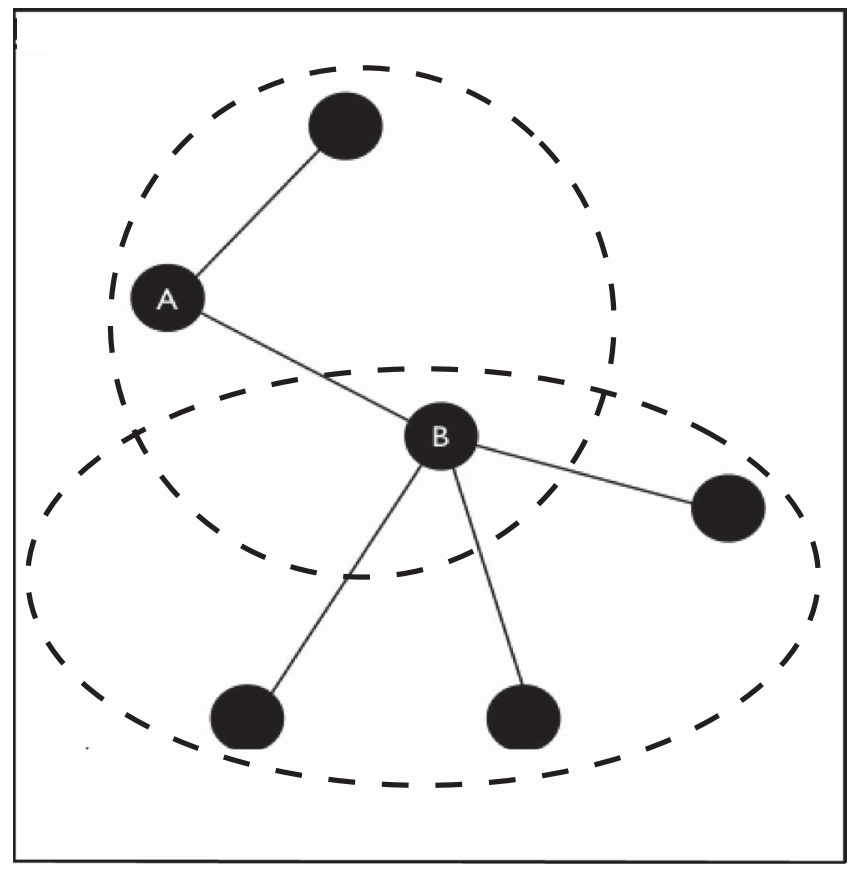

charting social networks is nothing more than a way of saying that people were in touch with each other. Network analysis can be very useful, however, for visualizing connections (see Figure 1). Networks are composed of nodes (in this case individuals or meeting places), clusters (groups of nodes), and links (the lines connecting the nodes). For the historian, the links are of special interest because they represent the ties connecting people. With regard to this, conventional network analysis, with an emphasis on quantifying and measuring ties, has less to offer, but perspectives from other disciplines more suited for qualitative analyses might help. The economic historian and Nobel laureate Douglass C. North, aided by John Joseph Wallis and Barry R. Weingast, recently developed North's earlier work on new institutional economics into a set of analytical tools, which allows the study of human societies regardless of geographical and chronological setting. ${ }^{16}$ The authors address the Weberian observation that all human societies have to deal with the problem of containing violence. This, according to North et al., is achieved by means of organizations and institutions. By 'organizations' they mean groups of people acting in at least a partly coordinated way and with the aim of controlling economic resources. ${ }^{17}$ Networks, whether

Press; and the Tom Brughmans, Anna Collar, and Fiona Coward, eds., The connected past: challenging networks in archaeology and history, Oxford: Oxford University Press, forthcoming.

16 Douglass C. North, John Joseph Wallis, and Barry R. Weingast, Violence and social orders: a conceptual framework for interpreting recorded human history, Cambridge: Cambridge University Press, 2009.

17 Ibid., p. 15. 
of the trading diaspora or the circulation society type, can be described as organizations in this sense. Links can be approached as 'institutions': 'the rules of the game, the patterns of interaction that govern and constrain the relationship of individuals' ${ }^{18}$

In order to understand merchant communities in the Indian Ocean, we need to investigate these institutions. These would have been what helped dispersed merchant communities preserve the notion of a real or perceived homeland and their identity vis-à-vis host societies, the qualities that Brubaker suggests must be present for true diaspora communities. ${ }^{19}$ Below, the institutions underpinning three ancient networks will be investigated: those described in the first-century CE navigation and trade manual Periplus Maris Erythraei; those in the first- to third-century epigraphic record relating to the Syrian city of Palmyra; and those in descriptions by Christian travellers and traders in late antiquity. While it is clear that these sources all depict Indian Ocean trade from Egyptian, Mesopotamian, and arguably also Roman/Parthian/Sasanian metropolitan or imperial points of view, they nevertheless give insight into different ways of organizing ancient commerce that are of interest on proto-global or even global levels.

\section{Networks based on geography: the Periplus of the Erythraean Sea}

The Periplus of the Erythraean Sea is a report on Indian Ocean trade and navigation, written in koine Greek in the mid first century CE by a merchant from Egypt, ${ }^{20}$ which was then a part of the Roman empire. In sixty-six brief chapters, the work gives details on how and when to sail to different Indian Ocean destinations, what to buy and what to sell, and local political conditions relevant to visiting merchants. With some exceptions, the parts describing the Red Sea, the Gulf of Aden, and the Arabian and Indian coasts of the Arabian Sea seem to be based on first-hand knowledge or reliable reports, while the descriptions of the east coast of Africa below Ras Hafun, the Persian/Arabian Gulf, and the Bay of Bengal appear to be badly informed. ${ }^{21}$

The author of the Periplus is mainly concerned with the destinations and activities of merchants from Egypt, but he also provides information on other networks, although the description of these is very likely to be incomplete. ${ }^{22}$ In summary, we find networks centred on Egypt, the kingdoms of Saba-Himyar and Hadramawt in South Arabia, southern Mesopotamia (ruled by the Parthian/Arsacid empire at this time), the region called Ariakê in western India (the Kshatrapa kingdom), and the region known as Limyrikê in South India (early Tamil kingdoms) (see Figure 2). Explicit or indirect references to diaspora settlements in the Periplus are limited to Adulis in present-day Eritrea (section 6), Rhapta in East Africa (section 16), Socotra in the Indian Ocean (section 30), and Muziris in southern India (section 56), but, based on what we know about Indian Ocean trade from other periods and

18 Ibid.

19 Brubaker, 'The "diaspora" diaspora', pp. 5-6.

20 Casson, Periplus Maris Erythraei, pp. 6-8.

21 Seland, Ports and power, p. 15.

22 Ibid., pp. 67-9. 
Figure 2. Indian Ocean networks in the Periplus.

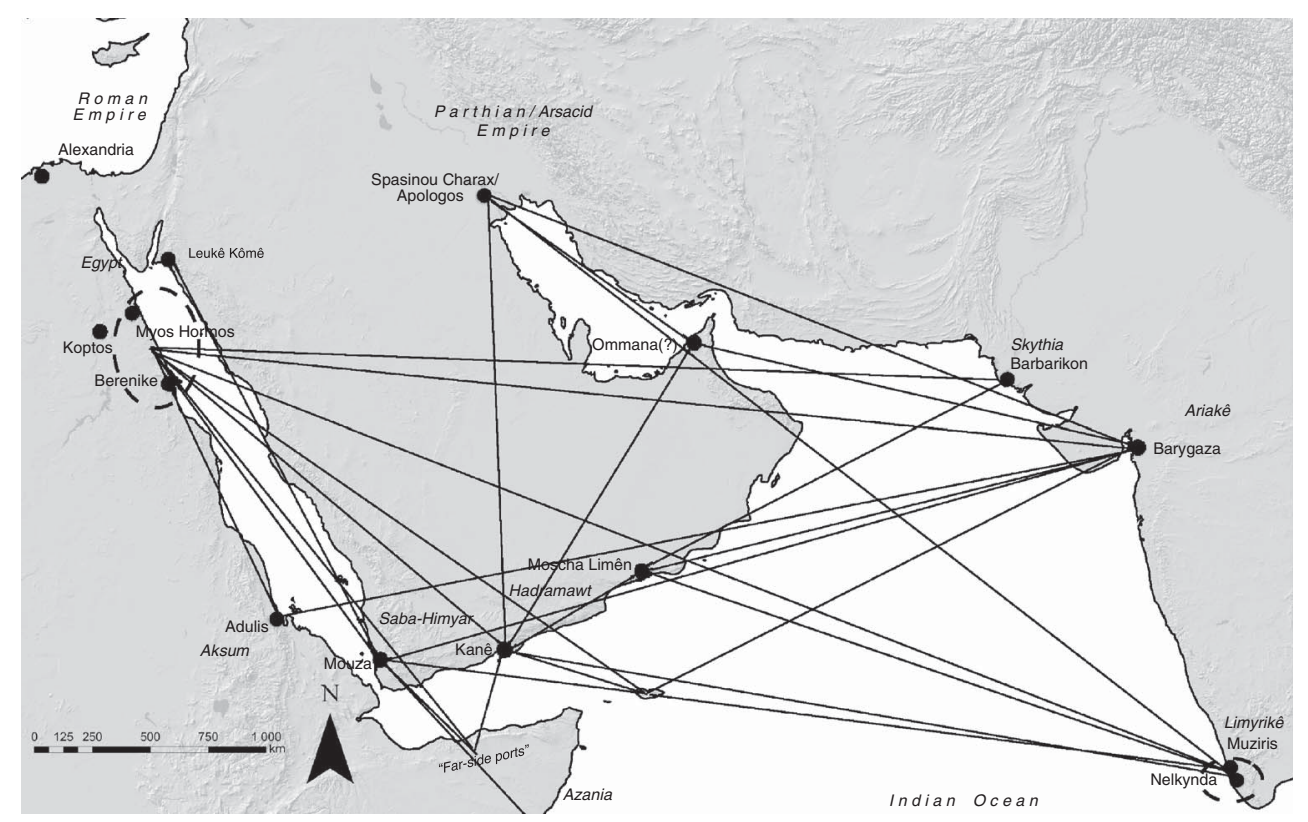

the seasonality of Indian Ocean navigation, it seems almost certain that at least some traders or other resident foreigners must also have been present in the other ports taking part in this trade. The material evidence from ancient port sites does not always offer the opportunity to draw conclusions on the ethnicity or origin of visiting and resident traders, but excavated port sites such as Pattanam (probably Muziris) and Arikamedu in India seem to have had a heterogeneous population. ${ }^{23}$ There are archaeological indications of residents of Indian origin from the Egyptian Red Sea ports of Berenike and Myos Hormos, ${ }^{24}$ as well as Khor Rori in modern Oman, ${ }^{25}$ and worshippers from India, Arabia, and Syria found their way to a cave sanctuary on the island of Socotra. ${ }^{26}$

Analysing the first-century networks described in the Periplus (see Figure 2) we find that merchants from Egypt traded with Adulis (section 6), ports in northern present-day Somalia (sections 8-14), Saba-Himyar and Hadramawt in South Arabia (sections 24, 28),

23 Tomber, Indo-Roman trade, pp. 147-51.

24 Sidebotham, 'Berenike', pp. 74-5; Ross Thomas and Paul Masser, '7.2. Trench 8', in David Peacock and Lucy Blue, eds., Myos Hormos - Quseir al-Qadim: Roman and Islamic ports on the Red Sea, volume 1: survey and excavations 1999-2003, Oxford: Oxbow, 2006, pp. 127-40.

25 T. S. Subramanian, 'Potsherd with Tamil-Brahmi script found in Oman', The Hindu, 28 October 2012, http://www.thehindu.com/news/national/potsherd-with-tamilbrahmi-script-found-in-oman/article4038866.ece (consulted 7 June 2013).

26 Hédi Dridi, 'Indiens et proche-orientaux dans une grotte de Suquțrā (Yemen)', Journal Asiatique, 290, 2 , 2002, pp. 565-610; Christian Robin and M. Gorea, 'Les vestiges antiques de la grotte de Hôq (Suqutra, Yémen)', Comptes Rrendus de l'Académie des Inscriptions et Belles-Lettres, 146, 2, 2002, pp. 409-45; Ingo Strauch, ed., Foreign sailors on Socotra: the inscriptions and drawings from the cave Hoq, Bremen: Hempen, 2012. 
Socotra (section 30), Barbarikon at the mouth of the Indus, Barygaza on the Narmada river (sections 39, 49), and Muziris and Nelkynda in South India (section 56). Merchants from South Arabia traded with Socotra (section 30), the coast of East Africa (section 16), the Nabataean kingdom in modern Jordan and Saudi Arabia (section 19), and ports of the Parthian empire (sections 27, 36), as well as Barbarikon (sections 27, 39), Barygaza (sections 21, 32, 49), and the region of Limyrike (section 32). Ships from ports in the Parthian empire are said to have visited South Arabia and Barygaza (section 36). Products from Ariakê were traded in Adulis (section 6), Somalia (section 14), Saba-Himyar (section 21), Hadramawt (sections 27, 32), Socotra (section 31), Parthian ports (section 36), South India (sections 51, 54), and the Coromandel Coast (section 51). Limyrikê traded with Socotra (section 31), Hadramawt (section 32), the Coromandel Coast (section 60), and ports in the Bay of Bengal (section 60).

In the Periplus these networks are described according to their geographical wellspring. In some cases this was a port, such as Barygaza, in other cases a region such as Arabia, Egypt, or Limyrikê (South India), or a polity, such as Persis (in this context the Parthian/Arsacid empire) or Ariakê (Kshatrapas). Occasionally, as in the description of the mixed population of Socotra (section 30), generalizing labels such as Greek (hellên), Arab (araps), and Indian (indos) are employed. These are clearly constructs, but they reflect how the author of the Periplus and presumably also his contemporary readership grouped people according to culture and geographical origin. Ethnicity, loosely defined as perceived common ancestry and boundary maintenance towards other groups, ${ }^{27}$ does not seem to have been the main cohesive institution of these networks, however. Most 'Greeks' encountered in the Indian Ocean world would have come from the Roman and Parthian empires, some perhaps also from the erstwhile Greek-ruled regions of north-western India. These regions were multicultural and highly heterogeneous societies, and this would probably also apply to their merchant populations. Studies of the perception of Greek identity in late Hellenistic Alexandria, a very relevant context for the Periplus, show that primary language, not descent, was the defining variable. Both individuals with Egyptian names and also Jews appear as 'Greeks' in documents, which makes Greek identity a matter of culture. ${ }^{28}$ In the Periplus, merchants from Arabia are not only described as Arabs (sections 16, 30) but are also identified by information on which city or kingdom they came from, signifying that they were not perceived as a homogenous group. India, as described in the Periplus, included the region eastwards to the Ganges, which was home to a number of peoples who would probably qualify as distinct ethnic groups.

If geographical origin was more important than ethnicity in bringing together people from Egypt or Mesopotamia when they were travelling to Arabia or India and vice versa, shared ties such as language, affiliation to a polity, and religion might have played a role in fostering cohesion. An ability to communicate in a common language, although not necessarily a first language, would have been a sine qua non among members of the network. The language situation of the Indian Ocean rim was complex, but presumably this language

27 Brubaker, 'The “diaspora” diaspora', pp. 5-7.

28 Jonathan M. Hall, Hellenicity: between ethnicity and culture, Chicago, IL: Chicago University Press, 2002, pp. 222-4; Dorothy J. Thompson, 'Language and literacy in early Hellenistic Egypt', in Per Bilde, Troels Engberg-Pedersen, Lise Hannestad, and Jan Zahle, eds., Ethnicity in Hellenistic Egypt, Aarhus: Aarhus University Press, 1992, pp. 50-1. 
would have been Greek in the case of the Egyptian network, Greek or Aramaic in the case of Mesopotamia, and dialects of South Arabian in the case of Saba-Himyar and Hadramawt. In north-western India, Prakrit, Sanskrit, and Greek are known from inscriptions and coin legends from this period, and further south on the subcontinent the use of Prakrit, Tamil, Old Sinhala, and Sanskrit - all written in Brahmi script - is documented from archaeological settings. ${ }^{29}$ Based on this evidence, Himanshu P. Ray has identified three language groups involved in overlapping trading networks in peninsular India. ${ }^{30}$ The excavations of Berenike, an important Red Sea port in Egypt, have so far unearthed texts in twelve different languages, underlining the cosmopolitan character of ancient Indian Ocean trade. ${ }^{31}$ In the cases of Egypt (Roman empire), Mesopotamia (Parthian empire), and Ariakê (Kshatrapas), networks also centred on a common polity and economy. This was probably important for merchants because, even if ancient states were not homogenous and integrated economies, merchants would have dealt with the same set of more or less familiar laws, political institutions, and monetary systems throughout the region. This was not necessarily the case for South Arabia and South India, as the regions were politically fragmented in the period. As for religion, merchants originating from the same region would also have been familiar with a shared polytheistic pantheon, although they may well have held different preferences within it.

Affiliation to a polity was determined by geographical origin, and geography would normally also influence language and religion. On the one hand this means that networks were characterized by relatively open access: merchants sailing out from Egypt on Egyptian ships would probably have been oriented towards a common homeland, regardless of whether they originally came from Syria, Greece, Egypt, or Arabia. They would all to some extent have been able to communicate in Greek and to relate to the same political and economic frameworks (the Roman empire and Roman Egypt), and they would have been familiar with a shared Mediterranean pantheon. On the other hand, such networks would probably also have been characterized by weak cohesion, because the institutions connecting the members of the network when they were abroad were of little importance at home. Once back in Egypt, a network of merchants from the Roman empire would disintegrate into Syrians, Greeks, Egyptians, and Arabs communicating in Aramaic, Greek, Demotic, and Arabic. A Mediterranean/Near Eastern pantheon, which might have seemed shared compared to its South Arabian or Indian counterparts, would dissolve into a Syrian Bel, a Greek Zeus, and an Egyptian Amon, who, although they were identified with each other, were also deities connected to different places and groups.

The apparent fragility of a network based on origin may seem like a major weakness but, looking more closely, the flexibility of such networks might also be the key to understanding their success. The networks encountered in the Periplus seem to fit into the pattern of those studied by Mark S. Granovetter in his modern network classic, The strength of weak ties. ${ }^{32}$ Granovetter argued that weak connections facilitate integration precisely because they are

29 Himanshu Prabha Ray, 'Inscribed pots, emerging identities: the social milieu of trade', in Patrick Olivelle, ed., Between the empires: Society in India 300 BCE to 400 CE, Oxford: Oxford University Press, 2006, pp. 113-43, esp. p. 121.

30 Ibid., p. 121.

31 Sidebotham, 'Berenike', p. 55.

32 Mark S. Granovetter, 'The strength of weak ties', American Journal of Sociology, 78, 6, 1973, pp. 1360-80. 
open and easy to form, while strong ties lead to fragmentation because they depend on prolonged contact and interdependence.

\section{A network based on ethnicity: the case of Palmyra}

Epigraphic material from the Syrian city of Palmyra allows a glimpse of a different way of organizing social networks. The city played an important role in the trade between the Indian Ocean and the Mediterranean in the first three centuries $\mathrm{CE},{ }^{33}$ taking part in maritime commerce by way of the Persian Gulf and the Red Sea, in addition to overland caravan trade across the Syrian Desert. ${ }^{34}$ The commercial activities of Palmyra are mostly known from epigraphic evidence. A body of about thirty so-called 'caravan inscriptions' from Palmyra itself commemorates the successful return of caravans from the Persian Gulf and documents the presence of Palmyrene individuals and communities in Mesopotamia, as well as their trade with north-western India. ${ }^{35}$ There are also some eighty inscriptions found outside Palmyra referring to people from the city. Many of these were dedicated by auxiliary soldiers in Roman service in Dacia (modern Rumania) and Numidia (modern Algeria). Others, however, refer explicitly to Palmyrenes taking part in Red Sea trade ${ }^{36}$ or have been found in locations that make connections with commercial activities a likely explanation for their presence, such as the commercial suburb of Transtiberim (Trastevere) in Rome, ${ }^{37}$ the Red Sea port of Berenike in Egypt, ${ }^{38}$ Wadi Hadramawt in Yemen, ${ }^{39}$ and Socotra in the Arabian Sea. ${ }^{40}$ If we include inscriptions found in places on the probable routes of communication between Palmyra and the Red Sea and Persian Gulf ports, ${ }^{41}$ we arrive at a possible layout of a Palmyrene commercial network (see Figure 3). As was the case with the networks described in the Periplus, this representation is very likely to be incomplete, as merchants and other people from Palmyra would have visited, lived in, and worked in places where they left no epigraphic record surviving to the modern period.

33 Javier Teixidor, 'Un port romain du désert: Palmyre et son commerce d'Auguste à Caracalla', Semitica, 34, 1978, pp. 1-127; Michel Gawlikowski, 'Palmyra as a trading centre', Iraq, 56, 1994, pp. 27-33; Michel Gawlikowski, 'Palmyra and its caravan trade', Les Annales Archeologiques Arabes Syriennes, 42, 1996 pp. 139-44; John F. Healy, 'Palmyra and the Arabian Gulf trade', ARAM, 8, 1996, pp. 33-7.

34 Seland, 'Persian Gulf', pp. 398-409.

35 List in Jean-Baptiste Yon, Les notables de Palmyre, Beyrouth: Institut Français d'Archéologie du Proche Orient, 2002, pp. 262-3.

36 Jean Bingen, 'Une dédicace de marchands palmyréniens à Coptos', Chronique d'Égypte, 59, 1984, 118, pp. 355-8; André Bernand, Les portes du désert recueil des inscriptions grecques d'Antinooupolis, Tentyris, Koptos, Apollonopolis Parva et Apollonopolis Magna, Paris: Centre National de la Recherche Scientifique, 1984, pp. 146-7, 262-3.

37 Yon, Notables de Palmyre, p. 272.

38 M. Dijkstra and A. M. F. W. Verhoogt, 'The Greek-Palmyrene inscription', in S. E. Sidebotham and W. Z. Wendrich, eds., Berenike 1997: report of the 1997 excavations at Berenike and the survey of the Egyptian Eastern Desert, including excavations at Shenshef, Leiden: CNWS, 1999, pp. 207-18.

39 F. Bron, 'Palmyreniens et chaldeens en Arabie du sud', Studi epigrafici e linguistici sul Vicino Oriente antico, 3, 1986, pp. 95-8.

40 Robin and Gorea, 'Vestiges antiques', p. 436.

41 See Yon, Notables de Palmyre, p. 273. I have left out the Palmyrene inscriptions from the Jewish cemetery of Beth Shearim in Galilee, as they are likely to belong to religious contexts rather than commercial. 
Figure 3. The network of Palmyra.

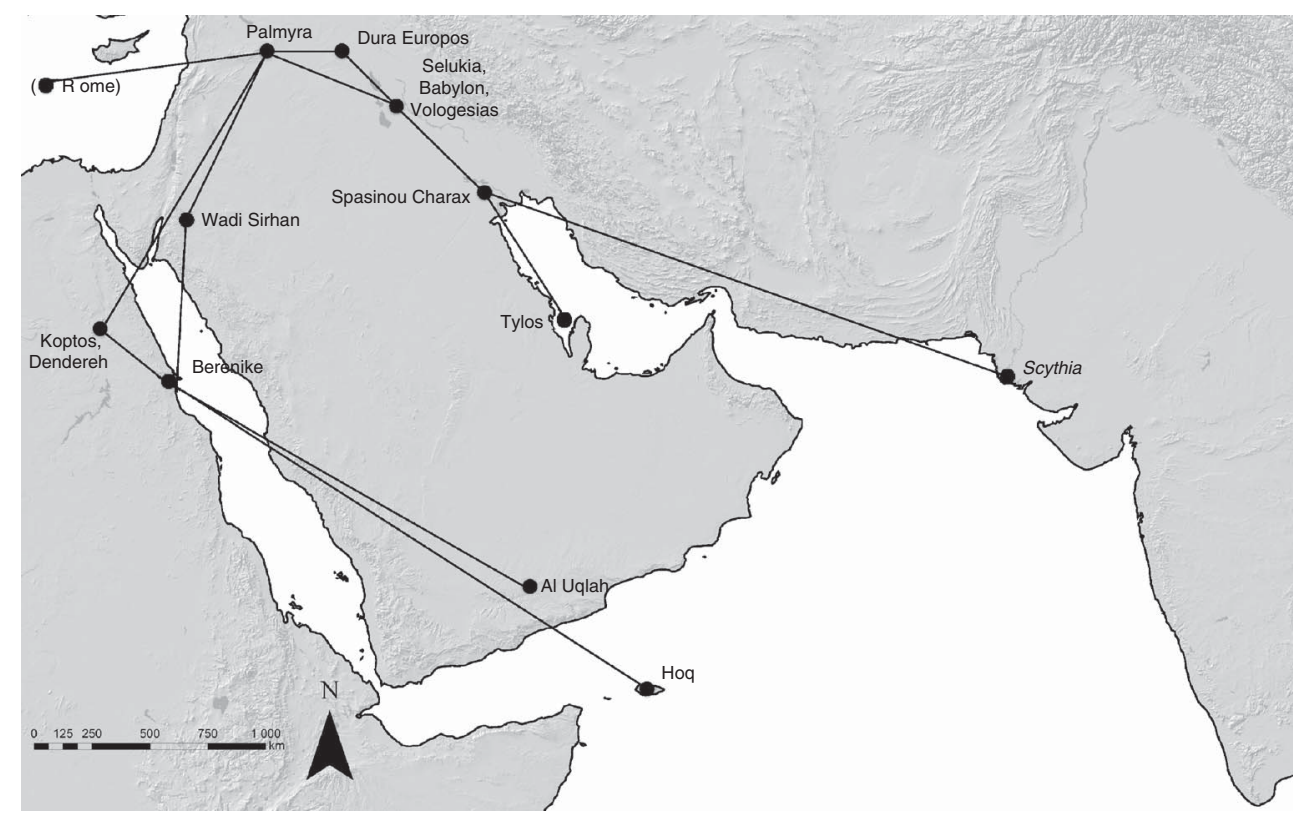

The Palmyrene network seems to have been a diaspora in the traditional sense of the word, exhibiting all three criteria of a true diaspora society as defined by Brubaker. ${ }^{42}$ First, its members were geographically widely dispersed. Second, they showed their orientation towards a real homeland, the city of Palmyra, by means of one or more of the criteria making it possible for us to identify them as Palmyrenes: use of the Palmyrene Aramaic language, explicit references to Palmyrene origin, and/or references to the Palmyrene pantheon. Third, they used their own language and references to their own pantheon as an effective way of preserving a separate identity within their host societies.

Several institutions kept the Palmyrene network together. The widespread use of a common language, Palmyrene Aramaic, even if regularly used alongside Greek (and, in a few cases, Latin), is significant, as most other societies in Roman Syria and elsewhere in the Roman East utilized Greek alone in public inscriptions. Kinship ties and descent were also clearly important, as reference is frequently made not only to the father but also to the paternal grandfather and great-grandfather of the person dedicating or honoured in an inscription. Tribal affiliation may have played a role, as we know that the population of Palmyra was organized into tribes, although it is not clear whether these were based on real or perceived common ancestry or were instead of purely political and administrative nature like those in many Mediterranean communities. It is also not known whether the nature of these tribes changed over the course of the nearly three centuries covered by the inscriptional record. ${ }^{43}$

42 Brubaker, 'The "diaspora” diaspora', pp. 5-6.

43 See Michael Sommer, Roms orientalische Steppengrenze: Palmyra, Edessa, Dura-Europos, Hatra: eine Kulturgeschichte von Pompeius bis Diocletian, Stuttgart: Franz Steiner, 2005, pp. 175-83; Yon, Notables de Palmyre, pp. 57-77. 
Politically, Palmyra was organized as a Hellenistic-style city-state, and many or most free, male, adult inhabitants, would have belonged to the citizenry, taking part in the civic life of the city together. ${ }^{44}$ Inscriptions from Palmyra also reveal professional and religious associations of different kinds, for instance an association (symposion) of tanners and floatingskin-makers (askonautopoioi), ${ }^{45}$ the latter activity almost certainly being connected to downriver transport of trading goods on the Euphrates on kellek, rafts supported by inflated skins. ${ }^{46}$ Religion would also have been a point of contact for members of the Palmyrene network, as most of them shared a pantheon different from, although not incompatible with, the Greco-Roman pantheon worshipped elsewhere in the eastern Mediterranean, and the Near Eastern religions practised by Palmyra's eastern neighbours. ${ }^{47}$ In the case of Palmyra, it seems justified to speak of a distinct ethnic identity: Palmyreans certainly considered themselves different from other people. ${ }^{48}$ This is visible not only in language, tribal organization, and religion, but also in the unique but syncretizing art, architecture, and burial customs of the city. ${ }^{49}$ The main way of becoming a member of the Palmyrene community would have been to be born into it.

The Palmyrene case represents a marked difference from the networks based on geographical origin described in the Periplus because institutions such as kinship, tribal affiliation, and citizenship were important not only abroad but also at home. If Palmyrene merchants abroad failed to live up to expected standards when dealing with fellow Palmyrenes, this could potentially result in repercussions at home, where members of their extended family, tribe, or religious or professional association, or simply fellow citizens, would be in a position to exercise social or juridical pressure. The Palmyrene network can thus be described as characterized by closed access and strong cohesion, as it was difficult or impossible for outsiders to join and the institutions regulating interaction between members of the community were numerous and potentially strong. In addition to this, members of the Palmyrene network would also have had access to the social networks based on geographical origin described above. We know of several examples of Palmyrene individuals who were awarded Roman citizenship ${ }^{50}$ and who held civic and royal offices in the Parthian empire. ${ }^{51}$ This means that when Palmyrene merchants sailed out of Egyptian or Mesopotamian ports, they possessed the cross-cultural skills and expertise needed to integrate seamlessly with other merchants coming from the Roman

44 Maurice Sartre, 'Palmyre: cité grecque', Annales Archéologiques Arabes Syriennes, 42, 1996, pp. $391-405$.

45 IGLS 17.59 = Jean-Baptiste Yon, Inscriptions greques et latines de la Syrie: Palmyre, Beyrouth: Institut Français d'Archéologie du Proche-Orient, 2012, no. 59.

46 Henri Seyrig, 'Les fils du roi Odainat', Annales Archéologiques de Syrie, 13, 1963, pp. 161-6.

47 See Ted Kaizer, The religious life of Palmyra: a study of the social patterns of worship in the Roman period, Stuttgart: Franz Steiner Verlag, 2002. There were also Jewish inhabitants of Palmyra, as the Palmyrene inscriptions from Beth Shearim document: see Yon, Notables de Palmyre, p. 273.

48 Yon, Notables de Palmyre, pp. 57-98.

49 Malcolm A. R. Colledge, The art of Palmyra, London: Thames and Hudson, 1976.

50 Using the adoption of Latin names alongside Palmyrene as a proxy, see the list in Yon, Notables de Palmyre, pp. 254-61.

51 Leonardo Gregoratti, 'The Palmyrenes and the Arsacid policy', in A. G. Avdeev, ed., Voprosy epigrafiki: sbornik statei (Problems of epigraphy: collected articles), vol. 4, Moscow: Russkij Fond Sodejstvija Obrazovaniju i Nauke, 2010, pp. 21-37. 
and Parthian empires. Thus they combined networks based on strong ties with networks based on weak ties.

The success of the Palmyrene network is evident in the widely spread epigraphic record, as well as in the wealth and power of the city itself, visible in its third-century attempt at imperial power and the lasting splendour of its ruins. It should also be noted, however, that the model proved to be vulnerable: no sign exists of Palmyrene activity outside Palmyra after the sack of the city by the Roman emperor Aurelian in 272-73. Again, this fits well with Granovetter's thesis that networks built on strong ties are vulnerable to fragmentation. ${ }^{52}$ The Palmyrene network in the Indian Ocean world revolved around its Syrian hub, and did not possess the necessary resilience and flexibility to withstand the Roman strike at its centre.

\section{Christianity: networks based on faith}

At the time that the Palmyrene network collapsed, a new model for the organization of social networks in the Indian Ocean world was emerging, one that would prove less vulnerable in the long run. Starting around $200 \mathrm{CE}$, it is possible to trace the emergence of Christian churches on the Indian Ocean rim. This is of particular interest because of our knowledge of the important role played by religion in Indian Ocean trade in the cases of Buddhism, ${ }^{53}$ Judaism, ${ }^{54}$ and Islam. ${ }^{55}$ In the centuries before the emergence of Islam, Christianity and, to some extent, Judaism were the expanding religions in the Indian Ocean. Christianity offered many of the same advantages to traders that other 'portable religions' did. ${ }^{56}$ 'Portable religions' refers to faiths that could be worshipped independently of place and primary social group. ${ }^{57}$ Ancient polytheistic religions were often celebrated together with members of one's own family, tribe, or city-state. Jews, Buddhists, Christians, and Muslims, however, were expected to worship together with co-religionists with whom they shared no ties apart from faith. Pagan gods were closely connected with their designated places of worship - the Palmyrene chief god Bel, for example, was a different deity from the Babylonian Bel and the Jupiter Baal of Heliopolis (Baalbek), or at least a clearly different aspect of the deity. Even if deities had a cosmological presence, the temple was also considered the actual, physical dwelling place of the god. By contrast, the same god was worshipped in the synagogues of Dura Europos in Syria, Beth She'arim in Galilee, and Qana in Yemen, and worship was also possible and expected outside such designated places.

52 Granovetter, 'Strength of weak ties'.

53 Himanshu P. Ray, Monastery and guild: commerce under the Satavahanas, New Delhi: Oxford University Press, 1986; Himanshu P. Ray, The winds of change: Buddhism and the maritime links of early South Asia, New Delhi: Oxford University Press, 1998.

54 Goitein, 'Portrait'; Goitein, Letters; Margariti, Aden; Goitein and Friedman, India traders.

55 Risso, Merchants and faith.

56 Eivind Heldaas Seland, 'Trade and Christianity in the Indian Ocean during late antiquity', Journal of Late Antiquity, 5, 1, 2012, pp. 72-86.

57 William McNeill, 'The era of civilizations in world history', Newsletter of the World History Association, 4, 1, 1987, pp. 1-4. 
Jonathan Z. Smith conceptualizes these differences by dividing religions into those that are practised 'here' (the domestic sphere), 'there' (the civic and national spheres), and 'anywhere'. ${ }^{58}$ While Palmyrene and other Mediterranean and Near Eastern polytheistic religions primarily belonged to the 'here' and 'there' groups, Judaism, Buddhism, Christianity, and, later, Islam were universal in the sense that they could be worshipped anywhere. Traders and travellers belonging to one of these could seek out the local community of co-religionists, and could reasonably expect to be welcomed there by people who could navigate in the local host culture as well as that of the visiting trader.

It is true that polytheistic religion also has elements of portability and aspects of 'religion anywhere'. Local versions of otherwise identical deities were worshipped in hundreds of shrines across the ancient world but, although two sea-captains from different places might offer sacrifice together in the temple of Neptune/Poseidon in their common port of call, they did not belong to a community of Neptune-worshippers, and preserved no social ties of a religious nature when they left the temple. Presumably this is also true for the remarkable cave sanctuary discovered at Socotra in 2000-01, where epigraphic sources document presence of worshippers from the Indian subcontinent, South Arabia, and Palmyra. ${ }^{59}$ Certain cults, notably the Roman imperial cult and so-called mystery cults such as the worship of the goddess Isis, had elements of personal membership and devotion. In an Indian Ocean context there is a reference to a templum Augusti (that is, a temple of the Roman imperial cult) in Muziris in South India on the fourth- or fifth-century CE road map known as the Tabula Peutingeriana, ${ }^{60}$ which, if correct, ${ }^{61}$ would have been a place where Roman citizens could come together to worship. The potential for symbiosis between trade and religion, however, was much greater in the widely dispersed Jewish and Christian communities of late antiquity, where believers could link up with co-religionists anywhere, regardless of whether they were in a place such as a temple, or had a specific status, such as citizenship.

An impression of the relationship between trade and Christianity in late antiquity can be pieced together from scattered reports in travel descriptions and church histories. It is clear that church officials and missionaries travelling in the Indian Ocean had to rely on commercial shipping, as other means of maritime passage were simply not available, and overland travel along the hot and arid coasts of the Red Sea and Persian Gulf was difficult at best. The third-century Acts of Judas Thomas describes how Thomas, the legendary founder of the Indian church and one of the disciples of Jesus, was sold into slavery and accompanied the merchant Habban on a ship to the Indo-Scythian kingdom on the Indus plain, where he set to work as a carpenter/architect on the royal palace of King Gondophares. ${ }^{62}$ The Acts, of course, are of legendary nature, but give a realistic image of the way in which people and

58 Jonathan Z. Smith, 'Here, there, and anywhere', in Jonathan Z. Smith, ed., Relating religion: essays in the study of religion, Chicago, IL, and London: Chicago University Press, 2004, pp. 323-38.

59 Dridi, 'Indiens'; Robin and Gorea, 'Vestiges antiques'; Strauch, Foreign Sailors.

60 Ekkehard Weber, Tabula Peutingeriana: Codex Vindobonensis 324: vollständige Faksimile-Ausgabe im Originalformat, Graz: Akademische Druck- u. Verlagsanstalt, 1976.

61 This is controversial: see Tomber, Indo-Roman trade, pp. 30, 148.

62 Acts of Judas Thomas, 2, translated in Albertus F. J. Klijn, The Acts of Thomas: introduction - text commentary, Leiden: Brill, 1962. 
religions might have moved in the region. Around the turn of the third century, a certain Pantainos is supposed to have undertaken a missionary journey from Egypt to India only to find that Christianity was already established there, and that local Christians read the scriptures in Hebrew, ${ }^{63}$ implying that the faith must have come by way of Mesopotamia, and perhaps that missionary work had taken place in the Jewish diaspora in India.

In the fourth century, two church historians provided reports about links between Christianity and commercial activities. Rufinus, writing about the conversion of the kingdom of Aksum in modern Ethiopia and Eritrea, c. 340-50, relates the story of Frumentius, a young boy from Tyre in modern Lebanon. He was captured and sold into slavery along with his companion Aedasius when their ship put in on the Aksumite coast in order to replenish its water supplies on the return journey from India. Eventually, the boys, being literate, were appointed stewards to the underage King Ezana. Frumentius used his influence to secure rights of worship and houses of assembly for Christian members of the Roman diaspora. Only after his manumission, following Ezana's majority, did he set out to convert the king and kingdom. ${ }^{64}$ A similar process can be seen in South Arabia some years later (c. $356 \mathrm{CE}$ ), when the imperial emissary Theophilus was sent to the king of Himyar, with instructions to ask for permission to establish churches for visiting Roman traders. Three churches were eventually built at the expense of the Himyarite king: at the capital Saphar, in Aden (described as the most important market town), and at an unidentified port at the mouth of the Persian Gulf. ${ }^{65}$ This suggests the presence of Christians in merchant diasporas before the formation of official church organizations.

By the sixth century, churches were present along most coasts of the western Indian Ocean (see Figure 4). The Christian topography of Kosmas Indikopleustes speaks of a church of Persian (Sasanian) Christians in Sri Lanka, maintaining ecclesiastical ties with Mesopotamia, c. 518 CE. Significantly, Christianity is reported to be a religion practised by the resident foreign diaspora, and thus presumably connected to trade, while the indigenous population is described as belonging to a different religion. ${ }^{66}$ Kosmas also notes Christian communities on the Malabar and Konkan coasts, on Socotra, in South Arabia, and in Ethiopia. ${ }^{67}$ Archaeologically, churches are attested in the Roman Red Sea ports of Aila and Berenike and the Aksumite port of Adulis. ${ }^{68}$ Nestorian sources attest the existence of churches on the eastern and southern shores of the Persian Gulf from the fourth century to

63 Euseb., Hist. ecc. 5.10, translated in C. F. Cruse, Eusebius' ecclesiastical history: complete and unabridged, Peabody, MA: Hendrickson, 1998.

64 Rufinus, Hist. ecc. 10.9-11, translated in Phillip R. Amidon, The church history of Rufinus of Aquileia, books 10 and 11, New York: Oxford University Press, 1997.

65 Philostorgius, Hist. ecc. 3.4, translated in Phillip R. Amidon, Philostorgius: church history, Atlanta, GA: Society of Biblical Literature, 2007. See also D. T. Potts, The Arabian Gulf in antiquity, volume II: from Alexander the Great to the coming of Islam, Oxford: Oxford University Press, 1999, pp. 330-3.

66 Kosmas, Top. Chr. 11.14, translated in Wanda Wolska-Conus, Topographie chrétienne, Paris: Cerf, 1968. The term used is allophyloi ('belonging to a different tribe'), but from the context it is clear that this refers to religious affiliation.

67 Kosmas, Top. Chr. 3.65-6.

68 Roberta Tomber, 'Bishops and traders: the role of Christianity in the Indian Ocean during the Roman period', in Janet Starkey, Paul Starkey, and Tony Wilkinson, eds., Natural resources and cultural connections of the Red Sea, Oxford: Archaeopress, 2001, pp. 220-1. 
Figure 4. Possible Christian network in the western Indian Ocean.

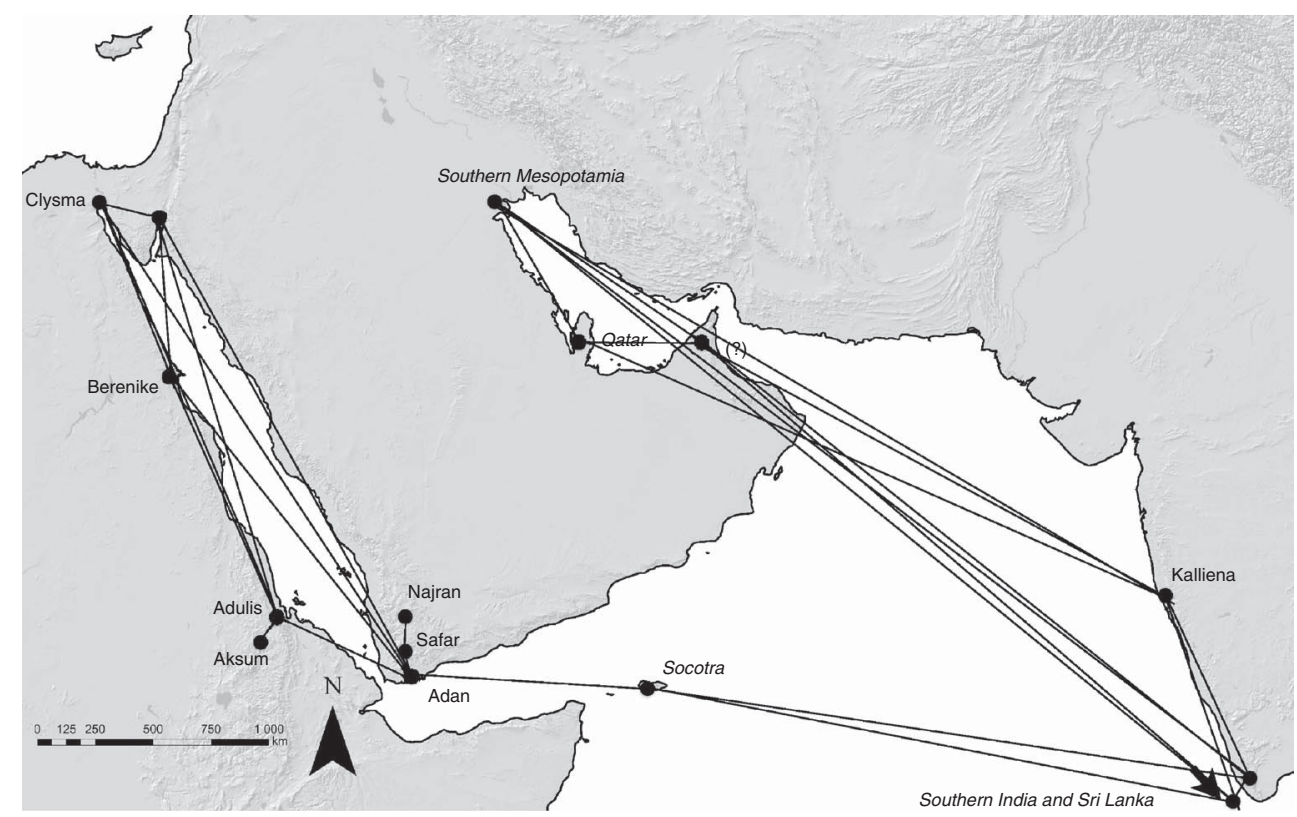

the ninth century, ${ }^{69}$ and archaeological remains of Christian monasteries have been found in several locations in the Gulf, seemingly indicating continued or even increased activity and prosperity in the early Islamic period. ${ }^{70}$ In the eastern Indian Ocean and also along the overland trade routes through Central Asia, Nestorian churches continue to thrive until at least the thirteenth century. ${ }^{71}$

These churches had practical significance for Christian merchants, allowing them to link up with co-religionists during their stays in Indian Ocean ports. Indications of a close relationship between Christian traders and churches are plentiful, ${ }^{72}$ although for the most part indirect. Potentially, this was not only a spiritual matter but also a way to find people whom you could trust. Christianity was an exclusive religion, not in the sense that it was difficult to join but in the sense that, once you were in, you were not supposed to take part in other religious cults. This means that Christian merchants who took their faith seriously

69 Aziz S. Atiya, A history of Eastern Christianity, Notre Dame, IN: University of Notre Dame Press, 1968, p. 258; Potts, Arabian Gulf, pp. 242-7, 330-3. J.-F. Salles, 'Fines Indiae - Ard el-Hind: recherches sur le devenir de la mer Erythrée', in Edward Dabrowa, ed., The Roman and Byzantine army in the East, Krakow: Unwersytet Jagielloński, 1994, pp. 175-82.

70 Peter Hellyer, 'Nestorian Christianity in the pre-Islamic UAE and southeastern Arabia', Journal of Social Affairs, 18, 72, 2001, pp. 80-99; R. A. Carter, 'Christianity in the Gulf during the first centuries of Islam', Arabian Archaeology and Epigraphy, 19, 1, 2008, pp. 71-108; Derek Kennet, 'The decline of eastern Arabia in the Sasanian period', Arabian Archaeology and Epigraphy, 18, 1, 2007, pp. 86-122.

71 K. Kévonian, 'Un itinéraire arménien de la mer de Chine,' in C. Guillot, ed., Histoire de Barus, Sumatra: le site de Lobu Tua I: études et documents, Paris: Archipel, 1998, p. 77.

72 Carter, 'Christianity in the Gulf'; B. C. Colless, 'The traders of the pearl', Abr Nabrain, 9, 1970, pp. 17-38. 
would be cut off from important arenas of interaction with pagan countrymen, including communal meals in connection with sacrifices. In a situation where Christianity was a minority religion (as it always remained in the Indian Ocean) and primarily a diaspora religion (as several of the sources cited above seem to indicate), it is reasonable to assume that this exclusivity would foster strong social cohesion with co-religionists, even in the absence of other social ties. As with the practices documented in the medieval letters from the Cairo Geniza, it is possible that Christian communities might have served as meeting places - network nodes - where transactions of business, credit, and information could take place.

Should the Christian merchant communities in the Indian Ocean be considered a trading diaspora? The network clearly lives up to two of the criteria held forth by Brubaker, ${ }^{73}$ namely dispersion and distinctive identity, but as this identity was connected to religion rather than place of origin, the network fails to meet the third criterion of a common homeland, at least in the visible world, although there was certainly a perceived otherworldly homeland awaiting the faithful after death. Moreover, the Christian commercial network was polycentric, thus resembling Aslanian's concept of a circulation society more closely than Curtin's trading diaspora. ${ }^{74}$ After the Nestorian schism of $431 \mathrm{CE}$, the Indian Ocean churches followed either the Roman or the Persian rite, maintaining ecclesiastical ties with either Alexandria (and thus Constantinople) or Ctesiphon respectively. The two church organizations competed fiercely for position and influence, but we do not know how important the schism was to ordinary believers. The presence of Christian merchants seems to have preceded that of formal church organization in the cases of Aksum (Ethiopia/Eritrea) and Himyar (South Arabia), ${ }^{75}$ and, arguably, it was more important for a merchant that there was a community of Christians whom he could link up with in ports of call or not than whether the church followed the Persian or the Roman rite.

In sum, the potential Christian network glimpsed in sources from the fourth to the sixth century CE is clearly different from those described in the Periplus and reconstructed from the Palmyrene epigraphic record. While the other networks can be described as trading diasporas oriented towards a homeland, the Christian network was polycentric, all nodes having the same rank when seen from the merchant's perspective (although not from the church's point of view). The Christian network had limited access: one had to be a believer in order to get in, and, once in, one was not supposed to be involved in competing religious networks. This potentially impeded interactions with non-Christian merchants from the same geographical region, ethnic group, or nationality, thus probably leading to a strong degree of cohesion between network members.

\section{Conclusion: overlapping social networks}

Most people are able to maintain multifaceted identities. This was also the case in the ancient world: Palmyrene merchants sailing out of Egypt and Mesopotamia were, for

73 Brubaker, 'The "diaspora" diaspora', pp. 5-6.

74 Curtin, Cross-cultural trade; Aslanian, From the Indian Ocean', pp. 1-22.

75 Eivind H. Seland, 'Trade and Christianity', pp. 80-3. 
instance, proficient in Greek and Aramaic (in some cases also in Latin and Hebrew), and operated on both sides of the border between the Roman and Parthian empires, even in times of conflict between the two. They were probably able to take part in the Egyptian and Mesopotamian networks described in the Periplus, but they also had additional support in the ethnically based Palmyrene community, which was not open to outsiders. Christian and Jewish merchants from the Roman and Sasanian (Neo-Persian) empires, would surely have been able to interact with pagan countrymen when they were abroad, even if perhaps not without friction, but they also had access to religious networks. These networks were not oriented towards a homeland, were durable as well as flexible, and were also off limits to non-believers, thus fostering strong cohesion between those connected by them. In the case of the Jewish network, the ethnic element comes in as a third pillar, perhaps contributing towards explaining its longstanding success. The Christian network was not equally successful in the long run. Although Christianity continued to flourish in South India, Ethiopia, Egypt, and Mesopotamia, links to commercial activities in the Indian Ocean were no longer evident in the Red Sea ports after the rise of Islam, and after the ninth century in the Gulf. ${ }^{76}$ The existence of a Christian diaspora in the western Indian Ocean in late antiquity nevertheless seems to have anticipated the Jewish and Islamic merchant communities of later periods. It represented a way of organizing trade that was distinct from the networks based on geography and ethnicity attested in the other case studies outlined above. The use of portable religion as a cohesive element in cross-cultural trade thus seems to have been a solution to the challenges of cross-cultural trade going back into the pre-Islamic period.

Why was the Christian network eclipsed? Again, Granovetter's insights on the strengths of weak ties might provide a clue. From the perspective of the merchant, ties of portable religion were of the weak kind, as the cohesion with otherwise unknown co-believers, strong as it might be during worship, declined very rapidly with distance in time and space. Christian mercantile networks, however, increasingly depended on hierarchical church organizations, backed or tolerated by political authorities as the religion became recognized and formalized in late antiquity. These church organizations were networks based on strong and formal ties, very vulnerable to fragmentation in the Indian Ocean setting, where the imperial backing available in the Roman empire - and to a certain extent even in the Sasanian world ${ }^{77}$ - did not exist. Jewish and Islamic networks, on the other hand, were polycentric, as much when viewed as religious networks as when seen as commercial.

In the first centuries CE, the western Indian Ocean was the hub of old-world exchange, and understanding the mechanisms of Indian Ocean commerce is vital for appreciating the scope and nature of proto-global interaction within the ancient oikumene. Approaching merchant communities, whether trading diasporas or circulation societies, in terms of social networks highlights the importance of ties between members or nodes. Investigating these ties sheds light on how such networks worked, and the theoretical dimension facilitates

76 Carter, 'Christianity in the Gulf'; Colless, 'Traders of the pearl', pp. 17-38.

77 Despite periodic persecutions, especially during conflicts with the Roman empire, the Nestorian church in Persia and Mesopotamia was generally tolerated, and, after 410 CE, actively supported by the Sasanian government as a useful rival to the Roman church. S. P. Block, 'Christians in the Sasanian empire: a case of divided loyalties', in Stuart Mews, Religion and identity, Oxford: Basil Blackwell, 1982, pp. 1-19; Hellyer, 'Nestorian Christianity', pp. 86-9. 
comparison with other geographical and empirical settings. An attempt has been made in this article to show how different models of organization had influence on the accessibility, strength, and vulnerability of networks, and how merchants could draw on multiple networks in order to establish the necessary infrastructure of trust. The Indian Ocean networks encountered in the ancient period bear strong resemblance to the organizational solutions familiar from more recent and more amply documented periods. With regard to global history, the most striking aspect of this is perhaps the resilience and longevity of such answers to the challenges to safety of life and property inherent to pre-modern trade.

Eivind Heldaas Seland works as principal investigator on the project 'Mechanisms of cross-cultural contact: networks in the Roman Near East'. He was previously a postdoctoral fellow on the project 'Palmyrena: city, hinterland and caravan trade between Orient and Occident'. Both projects are hosted by the Department of Archaeology, History, Cultural Studies and Religion, University of Bergen, and funded by the Research Council of Norway. 